\title{
BEHAVIOR OF A PORTABLE SOLAR DRYER FOR PINEAPPLE FIBER
}

\author{
Comportamento de um secador solar para fibras de abacaxi
}

\author{
Róger Moya ${ }^{1}$, MarcoSolano²
}

\begin{abstract}
In Costa Rica, there has been a growing interest to use pineapple fiber from plant, for which current processes need to be improved or new processes need to be developed, with emphasis on drying methods. This work presents the design and evaluation of the behavior of a prototype portable solar dryer in four sites of Costa Rica. The design describes the main parts of the dryer, as well as how they were constructed. The behavior was evaluated according to temperature and relative humidity inside e outside the chamber, and the influence of direct and indirect solar radiation. In order to achieve improved dryer efficiency, a dehumidifier was used to control relative humidity, and a heating system was implemented during the hours of low temperature, low solar radiation and high relative humidity. Based on drying time, final moisture content of fibers of pineapple leaves from plant, and the varying hours when fibers were put to dry, the evaluation of the dryer revealed that the best fiber-drying interval is from $6 \mathrm{~h} 00$ to $14 \mathrm{~h} 00$, and after that, it is convenient to inject hot air and use a dehumidifier in the dryer in order to increase its efficiency.
\end{abstract}

Index terms: Air drying, relative humidity, moisture content, temperature, solar radiation.

\section{RESUMO}

$\mathrm{Na}$ Costa Rica, o interesse pelo uso da fibra proveniente da folha de abacaxizeiro. Tem almentado e essa atividade precisa de melhoramento ou implementação de novos processos para alcançar maior eficiência, principalmente na secagem da fibra. O presente trabalho apresenta o design e comportamento de uma protótipo portátil de secadora solar em 4 sites geográficos da Costa Rica. Estão descritas as principais partes do secador, bem como a metodologia de construção. O comportamento foi avaliado de acordo com a temperatura e umidade relativa interna e externa da câmara e a influencia da radiação direta e indireta. Com a finalidade de melhorar a eficiência da secadora, foi usado um desumidificador para controlar a umidade relativa e ainda um sistema de aquecimento durante as horas de baixa temperatura e baixa radiação solar e nos períodos de alta umidade relativa. Foram avaliados o tempo de secagem, o teor de umidade final das fibras e a variação das horas que as fibras são colocadas no secador. O intervalo do dia onde apresenta as melhores condições para secagem é de $6 \mathrm{~h}$ até $14 \mathrm{~h}$. Após essa hora, é conveniente acrescentar ar quente e/ou desumidificador dentro do secador para aumentar sua eficiência.

Termos para indexação: Secagem no ar, humidade relativa, teor de humidade, temperatura, radiação solar.

(Received in october 9, 2012 and approved in november 8, 2012)

\section{INTRODUCTION}

Costa Rica has recently developed an interest in using the pineapple plant (ULLOA et al., 2004). However, for its proper usage it is necessary to have a drying process. Traditionally, Costa Rica has used different drying systems such as drying with electric ovens, or from the combustion of gas, petroleum or firewood (COSTALES, 2010). However, air drying is the most widely used system, with the disadvantage of reaching moisture content (MC) levels between 18 and 24\%, depending on the geographic region (SALAS et al., 2008).

Nowadays, solar energy drying systems have gained popularity (EKECHUKWU; NORTON, 1999), since it is an ecological alternative in agricultural production (COSTALES, 2010). There are many solar drying examples, such as for timber (SALAS et al., 2008) and for a great variety of food commodities (JANJAI et al., 2006; ZHIMIN et al, 2006; LOTFALIAN et al., 2010).

However, solar dryers have one drawback: they are dependent on solar radiation and on the variability of environmental conditions during the day, particularly regarding the presence or absence of clouds. Clouds may reflect up to $70 \%$ of solar radiation (AZHARI et al., 2008). Other factors may affect, such as the latitude, topography, soil reflectivity, water vapor content, aerosols in the atmosphere and day of the year (WRIGHT, 2002; AZHARI et al., 2008). In areas where solar light is abundant, the use of solar dryers reduces energy costs associated with conventional sources (OKALA et al., 2011).

Costa Rica has an average temperature of $14-27^{\circ} \mathrm{C}$ and an average relative humidity of $68 \%$, although these

\footnotetext{
'Escuela de Ingeniería Forestal - Instituto Tecnológico de Costa Rica - Apartado - 159-7050 - Cartago - Costa Rica - rmoya@itcr.ac.cr ${ }^{2}$ Escuela de Ingeniería Forestal - Instituto Tecnológico de Costa Rica - Apartado - Cartago-Costa - Rica
}

Ciênc. agrotec., Lavras, v. 36, n. 6, p. 674-683, nov./dez., 2012 
conditions may vary during the day: between $01 \mathrm{~h} 00$ and $8 \mathrm{~h} 00$ and after $15 \mathrm{~h} 00$, environmental humidity can be over $90 \%$, increasing during the rainy season (ALVARADO, 2001). Such climatic conditions do not allow for efficient solar drying systems, since there is constant need to exchange the air in inside chamber of the dryer with dry air from the outside chamber. Introduction of air with low relative humidity inside drying chamber permits efficient drying of the material.

In view of the problems of high relative humidity in the environment and the need to search for low-cost drying equipment to dry pineapple fiber for subsequent use, the present work's objective is to evaluate the efficiency on the field of a versatile solar dryer, as a proposal for fiber drying in different climatic scenarios.

\section{MATERIAL AND METHODS}

Portable solar dryer proposal: the dryer was designed to use materials that are commonly found in construction materials distributors (Figure 1a). The dryer has $3.0 \mathrm{~m}$ wide, $1.7 \mathrm{~m}$ deep and $1.9 \mathrm{~m}$ tall (Figures $2 \mathrm{a}$ and $2 \mathrm{~b}$ ) and it is easy to transported and assembled anywhere.
The dryer is made of two walls, four doors, a foldable top, a wooden base and floor, a baffle and a metallic solar collector.

Additionally, fans are needed for air circulation and a dehumidifier to decrease relative humidity $(\mathrm{RH})$ inside the chamber. Following are general specifications for the construction: Base and floor: a wooden base was constructed and prefabricated floor was placed on it (Figure 2c). Walls: they are made of wood, fiberglass as an isolator in the internal area, and flat zinc plates on the internal and external parts. One of the walls has four windows ( $40 \mathrm{~cm}$ wide and $40 \mathrm{~cm}$ tall) to allow air exchange within the chamber. Conventional lattice was installed in the vents to open and close them. Roof: it is made of aluminum tubes with $3 \mathrm{~mm}$ thick polycarbonate plates (Figure 2d). It can be folded into two halves; this design facilitates its manipulation and transportation. Also, a grid was built to give it further support and resistance (Figure 2d). Doors: they are covered internally and externally with flat zinc plates, with fiberglass filling in between. The dryer parts are assembly, firstly base and floor are located (Figure $2 \mathrm{c}$ ), afterwards two walls are fixed in the floor and joint

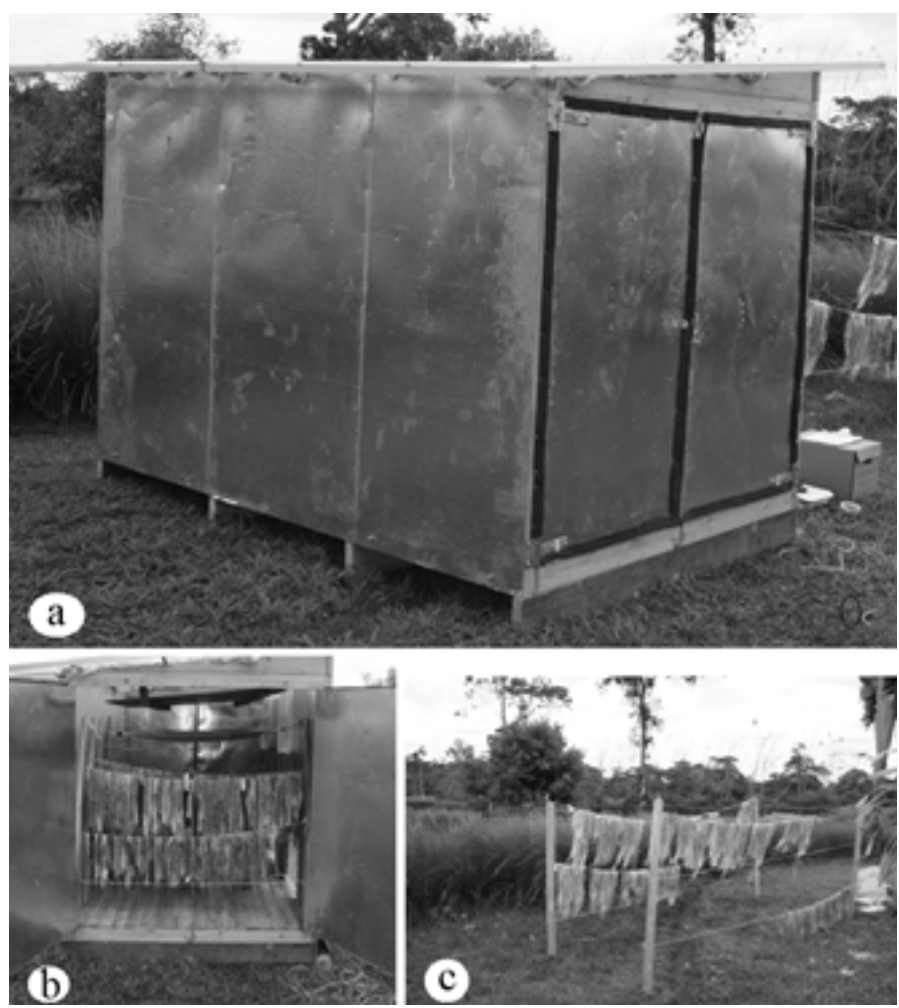

Figure 1 - General view of portable dryer pilot for drying pineapple leaves fiber (a), localization of fiber samples inside (b) and outside (c) the chamber. 
with two boards in the top (Figures $2 \mathrm{~g}$ ). The fiberglass roof is displayed (Figure 2d) and located in the top (Figure 2g).

The chamber is composted by a black painted iron plate and is placed within the dryer. Beneath the collectors is a baffle, to re-direct air currents within the drying chamber. Two fans, are found close to the vents on the upper side and they are directed towards the solar collectors, to form an air current. Control of relative humidity and temperature: to address the high $\mathrm{RH}$ conditions in Costa Rica a dehumidifier is proposed, which works with a solar panel. With regard to low temperature, a heat injection method was designed (Figure 2f), which consists of a gas burner that can either use Liquid Petroleum Gas (LPG) or otherwise be adapted for biogas.

\section{Evaluation of dryer efficiency with pineapple fiber}

Four tests to check the functioning of the dryer were carried out in four sites with diverse climatic conditions in Costa Rica (Figure 3). Efficiency evaluation considered: (i) temperature (IT) and relative humidity (IRH) inside the chamber; temperature and relative humidity (ET and ERH, respectively) outside chamber; (iii) direct and indirect solar radiation (DSR and ISR, respectively). To evaluate fiber drying, moisture content (MC) and drying time (DT) were considered, and ultimately the drying

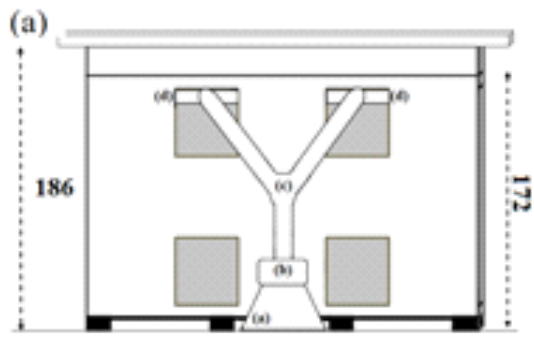

(d) Roof

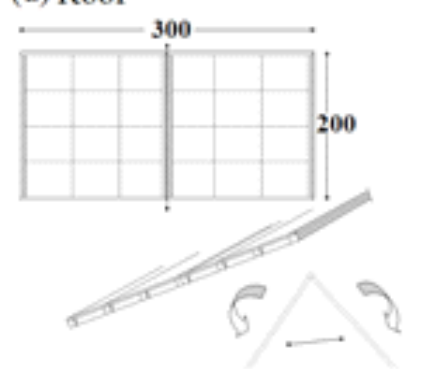

(e) Door

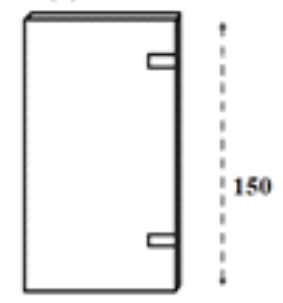

(g)

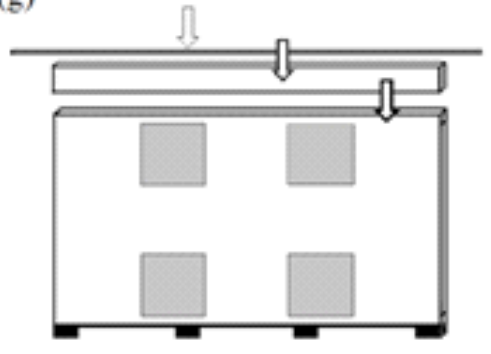

300

(b)

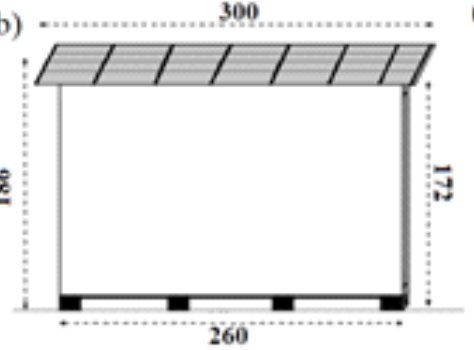

(f) (c) Floor.

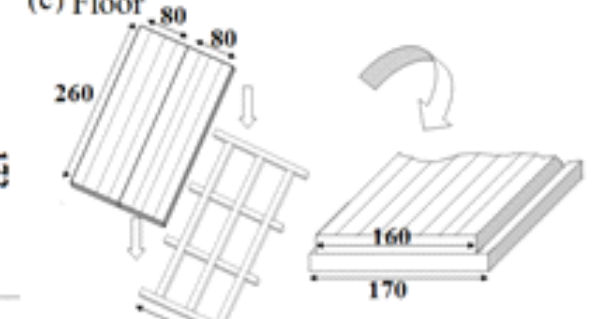

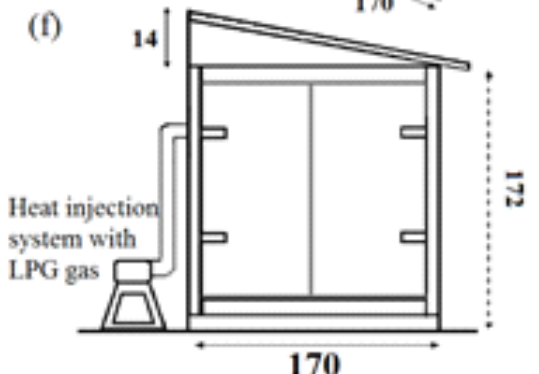

(h)

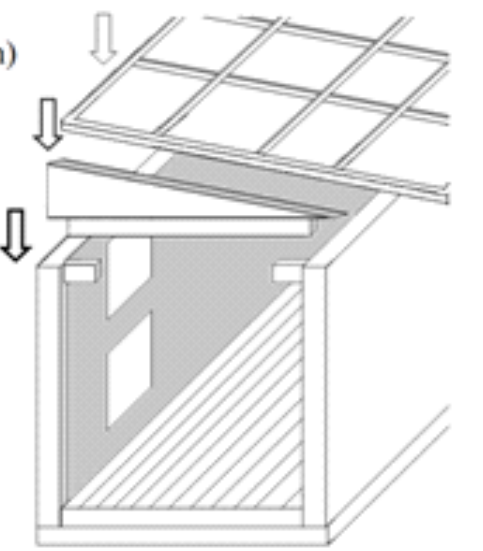

Figure 2 - Dimension $(\mathrm{cm}$ ) and assembly of portable pilot kiln (a and b). (a) heat injection system inside chamber by lateral side (c) wood floor assembly, (d) Fiberglass roof, (f) door (f) heat injection system (box burner and turbine pipe extractor) in side view, and (g) lateral assembly.

Ciênc. agrotec., Lavras, v. 36, n. 6, p. 674-683, nov./dez., 2012 
efficiency was compared with natural condition (outside) or air fiber drying.

Temperature, relative humidity inside and outside the chamber and radiation measurements: measurements of environmental variables were performed at 30 minutes intervals. A hygrometer was used for IT, ET and IRH measurements (Shack brand, Cat No 63-1032 model). ERH was determined with a portable meteorological station (Kestrel 3000). A pyranometer was used to measure DSR and ISR (Daystar's brand, DS-05A model). To take DSR measurements, the instrument was perpendicular to sun rays, while ISR measurements were taken on the dryer's top, maintaining the instrument with the same inclination and position of the roof.

Study sites and drying conditions: in four sites, a flat, open-spaced location was chosen. The dryer was positioned in a north (highest section) to south direction (lowest section) to obtain the highest solar radiation possible. The test dryings were carried out on Feb to Mar. Following is an outline of the order and conditions established for the drying tests:

- Río Cuarto of Grecia- Alajuela (10²6’09 N and $\left.84^{\circ} 14^{\prime} 58 \mathrm{~W}\right)$. Fans were placed on the floor of the drying chamber and the dehumidifier was not used to control IRH. Vents were opened and closed according to the chamber's IRH in order to regulate it (Figure 3).

- Guácimo-Limón $\left(10^{\circ} 10^{\prime} 25 \mathrm{~N}\right.$ and 8341 $\left.10 \mathrm{~W}\right)$ and Buenos Aires- Puntarenas $\left(9^{\circ} 12^{\prime} 07 \mathrm{~N}\right.$ and 83 $\left.3^{\circ} 8^{\prime} 19 \mathrm{~W}\right)$ : Fans were placed on the upper side of the chamber and the dehumidifier was used to control IRH. Vents were not opened (Figure 3).

- Cartago on the campus of the Instituto Tecnológico de Costa Rica-Cartago (950’59 N and 83 54`37 W) (Figure 3): Fans were used on the upper side, and the dehumidifier was used on the lower side. Additionally, the hot air system was implemented with the LPG gas burner (Figure 2f).

Pineapple fiber: Pineapple plants without fruit were used for fiber extraction. It was used their leaves with a length of $60-80 \mathrm{~cm}$. The fiber was extracted using a machine similar to that used for cabuya (Furcraea andina) fiber extraction (http://www.youtube.com/watch?v=AWBg80Z SUQU). Evaluation of the drying process was done during one work day per site, from $06 \mathrm{~h} 00 \mathrm{am}$ to $14 \mathrm{~h} 00 \mathrm{pm}$. In order to evaluate drying at different times of day, 6 samples were extracted every 1 or 2 hours within the work day. The

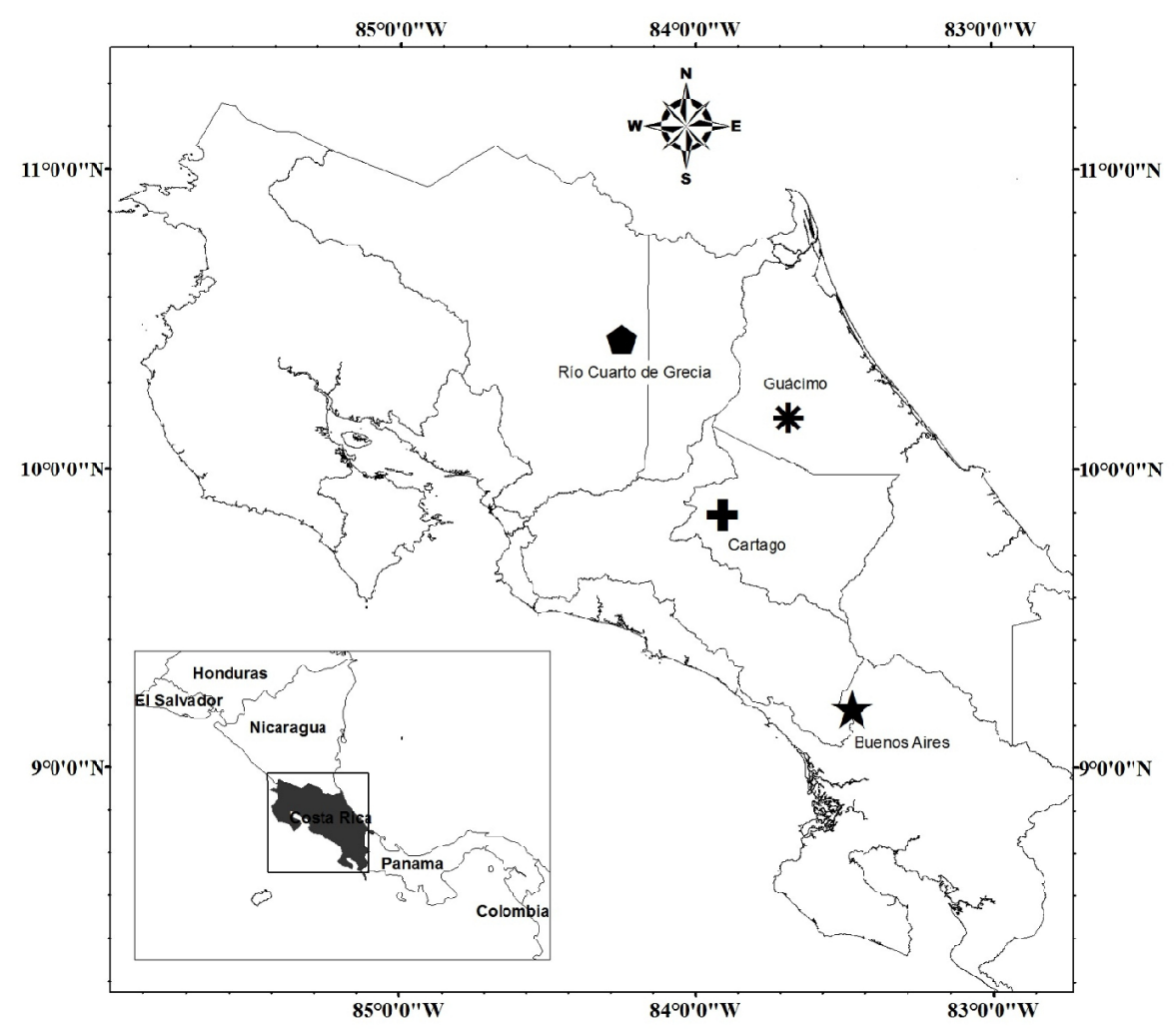

Figure 3 - Localization of studied in sites Costa Rica (Central America). 
samples had a varying weight of 250 to $350 \mathrm{~g}$. Each sample was divided into two lots; one for evaluating the solar dryer and the other served as a blank sample to evaluate air drying, except in the Rio Cuarto. The fiber samples in the air drying were not tested because we had problem with this.

Variation of the moisture content (MC) and drying time (DT): fiber samples were weighed at intervals. When temperature raised over $26^{\circ} \mathrm{C}$, they were weighed every hour; meanwhile, if the temperature was below $26^{\circ} \mathrm{C}$, the sample was weighed every 2 hours. Drying concluded once the samples reached their constant weight inside the chamber. Afterwards these samples were placed inside an oven at $103^{\circ} \mathrm{C}$ for 24 hours to determine MC (Equation 1), according to Samuelssona et al. (2006). DT was calculated by the amount of time required for samples to achieve $15 \%$ MC.

Material placement inside the chamber and outside: the material was placed under two conditions: inside or outside the dryer (control); the latter of which called air drying. Inside and outside the chamber the samples were placed on nylon racks (Figure $1 \mathrm{~b}$ and Figure 1c).

Statistical analysis: A descriptive research was performed on all studied variables. Maximum and minimum values, averages and standard deviations were calculated. Likewise, variables were tested to ensure they had normal distributions and homogenous variance. Next, an analysis of variance was done to verify differences between initial MC, final MC and DT in the different study sites and hours.
Significant differences between the average were verified through Tukey's test $(\mathrm{P}<0.01)$. Furthermore, the temperature change $(\Delta \mathrm{T})$ between IT and ET was calculated; following which a regression analysis to correlate this parameter with ET, DSR and ISR was performed.

\section{RESULTS AND DISCUSSION}

\section{Temperature and relative humidity conditions within the drying chamber}

The highest IRH was obtained in Río Cuarto, where dehumidifier was not used. IRH diminished to an average of 34 to $44 \%$ in sites where dehumidifier was used (Guácimo, Buenos Aires and Cartago) (Table 1). The highest average TI was found in Buenos Aires, whereas the lowest was found in Río Cuarto.

A comparison between IRH and ERH conditions revealed that when dehumidifier was not used in the dryer, such as in the case of Río Cuarto (Figure 4a), IRH was higher or very similar to ERH. Contrariwise, in sites where dehumidifier was used, IRH was always below ERH (Figures $4 b, 4 c$ and $4 d$ ). It is also important to observe that the maximum differences between IRH and ERH were found in Cartago (Figure 4d).

IT and ET shared a similar pattern in Río Cuarto (Figure 5a). In Guácimo (Figures 5b), both temperatures behaved as expected, increasing during the first morning hours and decreasing during the afternoon. Also, for the dryer to function optimally, IT was higher than ET in these

$\%$ Moisture Content $=\frac{\text { Green Weight }- \text { Dry Weight in Oven }}{\text { Green Weight }} * 100$

Table 1 - Relative humidity and temperature conditions inside the chamber, solar radiation and temperature change.

\begin{tabular}{lccccc}
\hline \multicolumn{1}{c}{ Variable } & General & Río Cuarto & Guácimo & Buenos Aires & Cartago \\
\hline Relative humidity inside the & $49(21.6)$ & $73(10.3)$ & $44(14.4)$ & $35(16.9)$ & $34(15.0)$ \\
chamber $(\%)$ & {$[92-10]$} & {$[92-53]$} & {$[92-24]$} & {$[83-20]$} & {$[83-10]$} \\
Temperature inside the chamber & $34(7.5)$ & $28(2.7)$ & $34(5.4)$ & $40(9.3)$ & $36(7.5)$ \\
$\left({ }^{\circ} \mathrm{C}\right)$ & {$[51-19]$} & {$[32-23]$} & {$[43-19]$} & {$[51-20]$} & {$[49-19]$} \\
Indirect solar radiation $\left(\mathrm{W} \mathrm{m}^{-2}\right)$ & $380(317.4)$ & $416(280.6)$ & $410(359.1)$ & $544(371.4)$ & $238(226.0)$ \\
& {$[1130-4]$} & {$[980-24]$} & {$[1130-4]$} & {$[984-5]$} & {$[725-9]$} \\
Direct solar radiation $\left(\mathrm{W} \mathrm{m}^{-2}\right)$ & $507(401.1)$ & $561(361.7)$ & $578(465.2)$ & $802(345.3)$ & $249(244.0)$ \\
& {$[1220-4]$} & {$[1175-48]$} & {$[1220-4]$} & {$[1053-5]$} & {$[839-9]$} \\
Variation of $\Delta \mathrm{T}\left({ }^{\circ} \mathrm{C}\right)$ & & -6 a 4 & $0-14$ & $0-14$ & $2-18$ \\
\hline
\end{tabular}

$(\ldots)=$ standard deviation,$[\ldots]=$ maximum and minimum, $\Delta \mathrm{T}=$ Temperature change between inside and outside 
sites. Lastly, in Cartago an increase in both temperatures was observed during the morning hours, and then it began to decrease. In this site the dryer can be expected to be more efficient, since IT was distinctly higher than ET (Figure 5d). It is important to note that in this site, with the aim to avoid IT decreasing within the drying chamber -as was observed in the two aforementioned sites- a heat source was applied when temperature started descending (at 16h00). This prevented IT from decreasing, and actually it rose close to $50^{\circ} \mathrm{C}$ (Figure $5 \mathrm{~d}$ ).

High IRH values found in Río Cuarto (Table 1) and their daytime behavior can be explained mainly by the region's high IRH, so IRH cannot be lowered by exchanging humid air within the dryer for drier air in the exterior. Another contributing factor is the low temperature found $\left(28^{\circ} \mathrm{C}\right)$. Another inconvenience for the solar dryer performance is that after $14 \mathrm{~h} 00$, the RH starts to increase reaching values close to saturation (close to $100 \%$ ) and causing IRH to rise after this hour (Figure 4), especially in Guácimo and Buenos Aires (Figure 4b and 4c). However, heat injection resolved this issue in the Cartago site, where IRH was below $40 \%$ (Figure 4d), and better drying efficiency was achieved. Such an improvement translated into shorter DT of less than 4 hours and 43 minutes, and less than $6.92 \%$ fiber MC (Table 2) due to the rise in temperature (Figure 4). Heat injection is a common practice that is carried out for low solar radiation conditions and during night hours.
The present study found that IT was normally higher than ET (Figure 5), the average variation being of $7^{\circ} \mathrm{C}$ between both. Major differences occurred between 10:00 and 14:00 hours (Figure 5). Finally, by changing the drying system and injecting hot air to increase temperature in low temperature hours and high ERH, conditions within the chamber were undoubtedly improved. Therefore, it solves the climatic condition problems of Costa Rica of high relative humidity values, especially early in the morning, during the afternoon, and with irregular solar radiation due to the presence of clouds.

\section{Effect of solar radiation and external temperature on the chamber's internal temperature}

As mentioned before, the effect of solar radiation was measured with the change of temperature between IT and $\operatorname{ET}(\Delta \mathrm{T})$. The $\Delta \mathrm{T}$ in Río Cuarto was low, from -6 to $4^{\circ}$ $\mathrm{C}$, followed by Guácimo and Buenos Aires, with a change from 0 to $14^{\circ} \mathrm{C}$, and then by Cartago with a $\Delta \mathrm{T}$ from 2 to $18^{\circ} \mathrm{C}$ (Table 1$)$.

\section{Pineapple fiber drying test}

Table 2 shows average initial moisture content (IMC), final moisture content (FMC) and DT for each site and time when fiber was placed. With regard to pineapple fiber IMC,- values ranged between 70 and $77 \%$, where average IMC was statistically equal ( $\mathrm{p}>0.05$ value) in all

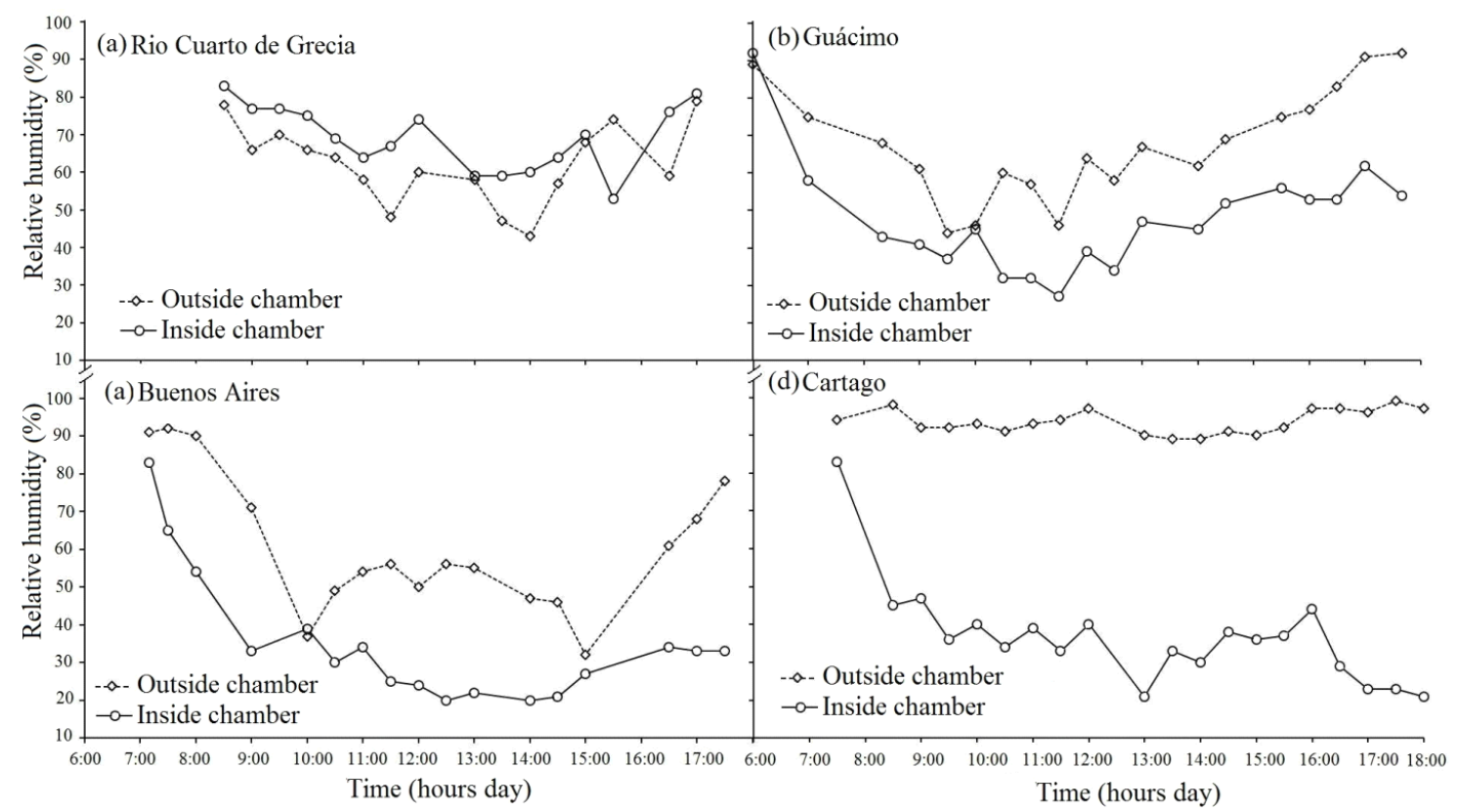

Figure 4 - Relative humidity inside and outside the chamber in four sites during different day time. 
sites and different hours day, except at 9h30 in Buenos Aires, where IMC was statistically different to all the other conditions. Moreover, FMC varied in every site and was relatively stable regarding the time fiber was placed in the chamber. The lowest FMC was found in Cartago, and the highest FMC in Río Cuarto. Not differences were found in FMC with respect to time of fiber placement in Cartago, but some differences were found in their sites (Table 2).

DT varied according to the site and the time when the fiber was placed to dry. Cartago presented the lowest DT, 3 hours and 44 minutes; followed by Buenos Aires and Guácimo with 4 hours and 59 minutes and 9 hours and 37 minutes, respectively. The longest DT was obtained in Río Cuarto. On the other hand, DT had the lowest values when fiber was placed within the dryer before $12 \mathrm{~h} 00$ in all sites. After that hour, the time needed may extend from 1 to 4 hours (Table 2). When analyzing DT, if a 15\% FMC was standardized, it was found that DT within the dryer was relatively constant between $07 \mathrm{~h} 00$ and $11 \mathrm{~h} 00-12 \mathrm{~h} 00$; if samples were placed after that hour, DT tended to increase in Buenos Aires (Figure 6a), Guácimo (Figure 6b) and Río Cuarto (Figure 6c), but in Cartago DT was fairly constant during the different hours (Figure 6d).

It was found that there was not visual difference between fiber quality dried in solar and natural condition. But when comparing FMC and DT results of solar drying and air drying, these parameters were related to the site and time of sample placement. In Buenos Aires, pineapple fiber placed inside the solar dryer when finalizing the drying had statistically equal FMC values ( $p>0.05$ value) to that obtained in air drying, but FMC was statistically inferior to air drying at $10 \mathrm{~h} 30$. In Cartago, all solar drying averages were lower than air averages, regardless of the time when pineapple fiber was placed (Table 2). As for DT, in Buenos Aires air drying had lower DT than those obtained with the solar dryer (Figure 6a). In Guácimo statistical differences were obtained from $9 \mathrm{~h} 00$ onwards $(\mathrm{p}<0.05$ value), and solar drying presented the lowest averages (Figure 6b). Finally, in Cartago (Figure 6d), solar drying had the lowest values at all fiber placement times than what was obtained by air drying.

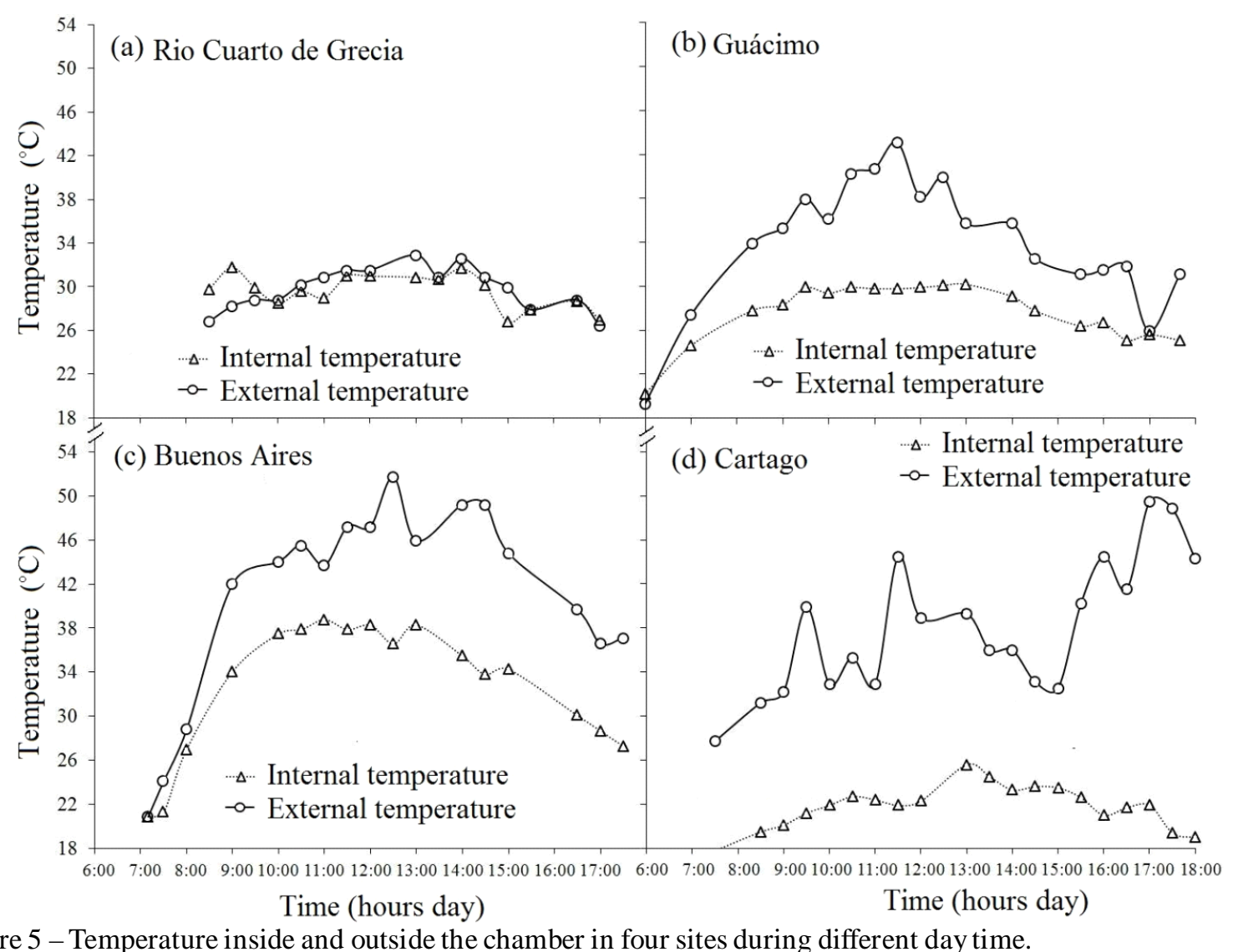

Figure 5 - Temperature inside and outside the chamber in four sites during different day time. 
Table 2 - Initial and final moisture content and drying time of pineapple leaves fiber in solar drying and natural dry for different hour's day in four sites of Costa Rica.

\begin{tabular}{|c|c|c|c|c|c|c|c|}
\hline \multirow{2}{*}{ Site } & \multirow{2}{*}{ Hour's Day } & \multicolumn{2}{|c|}{ Initial moisture content $(\%)$} & \multicolumn{2}{|c|}{ Final moisture content $(\%)$} & \multicolumn{2}{|c|}{ Drying time $(\mathrm{h})$} \\
\hline & & Solar drying & Air drying & Solar drying & Air drying & Solar drying & Aire drying \\
\hline \multirow{7}{*}{$\begin{array}{c}\text { Buenos } \\
\text { Aires }\end{array}$} & 07:00 & $77.47^{\mathrm{A}}$ & $74.67^{\mathrm{A}}$ & $9.32^{\mathrm{A}}$ & $7.48^{\mathrm{A}}$ & $4: 56^{\mathrm{B}}$ & $5: 32^{\mathrm{A}}$ \\
\hline & 08:00 & $76.59^{\mathrm{A}}$ & $75.20^{\mathrm{A}}$ & $8.00^{\mathrm{A}}$ & $9.62^{\mathrm{A}}$ & $4: 11^{\mathrm{A}}$ & $3: 32^{\mathrm{A}}$ \\
\hline & $09: 30$ & $73.78^{\mathrm{A}}$ & $70.36^{\mathrm{B}}$ & $8.93^{\mathrm{A}}$ & $8.94^{\mathrm{A}}$ & $4: 11^{\mathrm{A}}$ & $2: 20^{\mathrm{B}}$ \\
\hline & $10: 30$ & $73.24^{\mathrm{A}}$ & $72.93^{\mathrm{A}}$ & $13.17^{\mathrm{A}}$ & $9.38^{\mathrm{A}}$ & $4: 23^{\mathrm{A}}$ & $1: 16^{\mathrm{B}}$ \\
\hline & $12: 30$ & $70.78^{\mathrm{A}}$ & $73.23^{\mathrm{A}}$ & $8.95^{\mathrm{B}}$ & $31.87^{\mathrm{A}}$ & $6: 40^{\mathrm{A}}$ & $2: 02^{\mathrm{A}}$ \\
\hline & $14: 30$ & $74.55^{\mathrm{A}}$ & $73.25^{\mathrm{A}}$ & $13.67^{\mathrm{B}}$ & $30.61^{\mathrm{A}}$ & $5: 38^{\mathrm{A}}$ & $3: 25^{\mathrm{A}}$ \\
\hline & Average & 74.40 & 73.27 & 10.34 & 16.32 & $4: 59$ & 3:01 \\
\hline \multirow[t]{6}{*}{ Guácimo } & 06:00 & $72.63^{\mathrm{A}}$ & $73.86^{\mathrm{A}}$ & $11.81^{\mathrm{A}}$ & $13.59^{\mathrm{A}}$ & $6: 07^{\mathrm{A}}$ & $6: 53^{\mathrm{A}}$ \\
\hline & 07:00 & $74.14^{\mathrm{A}}$ & $75.84^{\mathrm{A}}$ & $15.16^{\mathrm{A}}$ & $20.36^{\mathrm{A}}$ & $7: 28^{A}$ & $6: 45^{\mathrm{A}}$ \\
\hline & 09:30 & $73.41^{\mathrm{A}}$ & $74.80^{\mathrm{A}}$ & $14.49^{\mathrm{B}}$ & $25.36^{\mathrm{A}}$ & $7: 37^{\mathrm{B}}$ & $16: 45^{\mathrm{A}}$ \\
\hline & $11: 30$ & $74.68^{\mathrm{A}}$ & $74.10^{\mathrm{A}}$ & $8.12^{\mathrm{B}}$ & $13.96^{\mathrm{A}}$ & $11: 20^{\mathrm{B}}$ & $21: 41^{\mathrm{A}}$ \\
\hline & $14: 00$ & $72.76^{\mathrm{A}}$ & $74.22^{\mathrm{A}}$ & $6.76^{\mathrm{B}}$ & $15.25^{\mathrm{A}}$ & $15: 35^{\mathrm{B}}$ & $19: 21^{\mathrm{A}}$ \\
\hline & Average & 73.52 & 74.56 & 11.27 & 17.70 & $9: 37$ & $14: 17$ \\
\hline \multirow[t]{8}{*}{ Cartago } & $07: 30$ & $74.08^{\mathrm{A}}$ & $74.30^{\mathrm{A}}$ & $5.26^{\mathrm{B}}$ & $12.96^{\mathrm{A}}$ & $3: 41^{\mathrm{B}}$ & $27: 00^{A}$ \\
\hline & 08:30 & $72.24^{\mathrm{A}}$ & $73.94^{\mathrm{A}}$ & $3.26^{\mathrm{B}}$ & $8.91^{\mathrm{A}}$ & $3: 40^{\mathrm{B}}$ & $26: 01^{\mathrm{A}}$ \\
\hline & 09:30 & $75.05^{\mathrm{A}}$ & $74.25^{\mathrm{A}}$ & $4.91^{\mathrm{B}}$ & $12.14^{\mathrm{A}}$ & $3: 36^{\mathrm{B}}$ & $25: 30^{\mathrm{A}}$ \\
\hline & $10: 30$ & $72.92^{\mathrm{A}}$ & $76.33^{\mathrm{A}}$ & $3.76^{\mathrm{B}}$ & $13.01^{\mathrm{A}}$ & $3: 03^{\mathrm{B}}$ & $24: 48^{\mathrm{A}}$ \\
\hline & $11: 30$ & $74.80^{\mathrm{A}}$ & $74.14^{\mathrm{A}}$ & $4.91^{\mathrm{B}}$ & $12.22^{\mathrm{A}}$ & $3: 56^{\mathrm{B}}$ & $23: 53^{A}$ \\
\hline & $13: 00$ & $75.32^{\mathrm{A}}$ & $73.36^{\mathrm{A}}$ & $6.92^{\mathrm{B}}$ & $10.80^{\mathrm{A}}$ & $4: 43^{\mathrm{B}}$ & $22: 26^{\mathrm{A}}$ \\
\hline & $14: 00$ & $75.26^{\mathrm{A}}$ & $76.32^{\mathrm{A}}$ & $5.47^{\mathrm{B}}$ & $16.81^{\mathrm{A}}$ & $3: 33^{\mathrm{B}}$ & $23: 11^{\mathrm{A}}$ \\
\hline & Average & 74.24 & 74.66 & 4.93 & 12.41 & $3: 44$ & $24: 41$ \\
\hline \multirow{9}{*}{$\begin{array}{c}\text { Río } \\
\text { Cuarto* }\end{array}$} & 06:00 & 75.19 & - & 37.98 & - & $9: 33$ & - \\
\hline & 07:00 & 76.00 & - & 47.04 & - & 9:07 & - \\
\hline & 08:00 & 73.03 & - & 35.68 & - & $7: 37$ & - \\
\hline & $10: 00$ & 74.49 & - & 28.76 & - & $8: 28$ & - \\
\hline & $11: 00$ & 71.95 & - & 30.49 & - & $8: 25$ & - \\
\hline & $12: 00$ & 72.50 & - & 20.76 & - & $25: 32$ & - \\
\hline & $13: 00$ & 73.98 & - & 20.37 & - & $25: 18$ & - \\
\hline & $14: 00$ & 74.52 & - & 21.75 & - & 24:08 & - \\
\hline & Average & $73.96^{)}$ & - & 30.35 & - & $14: 46$ & - \\
\hline
\end{tabular}

Legend: Different letters between solar and air drying are statistically different at $99 \%$.

*The fiber samples in the air drying were not determined because some problems were presented.

Average IMC found for pineapple fiber (Table 2) was similar to that reported by Pangavhane et al. (2002), who found values between 60 and $80 \%$. The difference found at $9 \mathrm{~h} 30$ in Buenos Aires was probably due to using drier pineapple leaves at the time, which resulted in low IMC.
DT and FMC are mostly influenced by the time of day when fiber is put to dry, independently from the geographic region where the dryer is located. Samples placed after $12 \mathrm{~h} 00$ require more DT, and higher MC levels are reached, than those placed from $6 \mathrm{~h} 00$ to $11 \mathrm{~h} 00$ (Table 2). This problem accentuates further after $12 \mathrm{~h} 00$ in Buenos 
Aires, Guácimo and Rio Cuarto (Figure 6). Once again results confirm that, due to environmental conditions in Costa Rica, after 14h00 the ERH conditions (Figure 3) and ET (Figure 4) increases, causing an increase in DT and a high FMC.

Solar dryer efficiency is evidenced by DT reduction. According to DT results (Figure 5), the dryer designed presented the best results in Cartago, where DT was lower; followed by Buenos Aires, Guácimo and Río Cuarto (Table 2, Figure 5). The site at Río Cuarto stands out for having the highest IRH (Table 1, Figure 3), low indirect and direct solar radiation (Table 2), and low temperature (Figure 4a). These conditions increased DT (Figure 5c) and FMC for pineapple fiber (Table 2) compared to the other study sites. Notwithstanding, when RH was improved within the chamber for Guácimo and Cartago, DT fell (Figure 5), particularly in Cartago, when hot air was injected during low efficiency drying hours. This site showed that all the practical modifications implemented to improve drying efficiency had a satisfactory outcome.

When comparing DT and fiber MC with air drying, solar drying proved advantageous when samples were placed after 10h30 in Buenos Aires, 9h30 in Guácimo, and at any time in Cartago since it presented lower values at all times and had low FMC. For pineapple fiber it can be affirmed that solar drying is more efficient than air drying. However, in some sites a combination of the two may help to improve drying efficiency, since under certain circumstances air drying is better than solar drying; i.e. in the Buenos Aires site. Interestingly, during the dry season, when the test was carried out in this site, air drying lowered DT and FMC by almost two hours compared to solar drying (Table 2). Nonetheless, to dry pineapple fiber completely, with air drying it does not reach the FMC and time achieved with the solar dryer (Figure 6a and 6b). Therefore, to achieve maximum dryer efficiency, fiber can be left out to dry during the first two hours after it has been extracted from the leaf, and then it may be introduced in the solar dryer, to finish drying at adequate FMC.

Another major outcome when comparing solar dryer with air drying was evidenced in Cartago. This site had the unfavorable temperature and RH outside chamber in all sites, and obtained the best solar drying efficiency, with significant differences between solar and air drying (Table 2). This suggests that when environmental conditions are of low temperature and high relative humidity, the solar dryer's potential is highe.

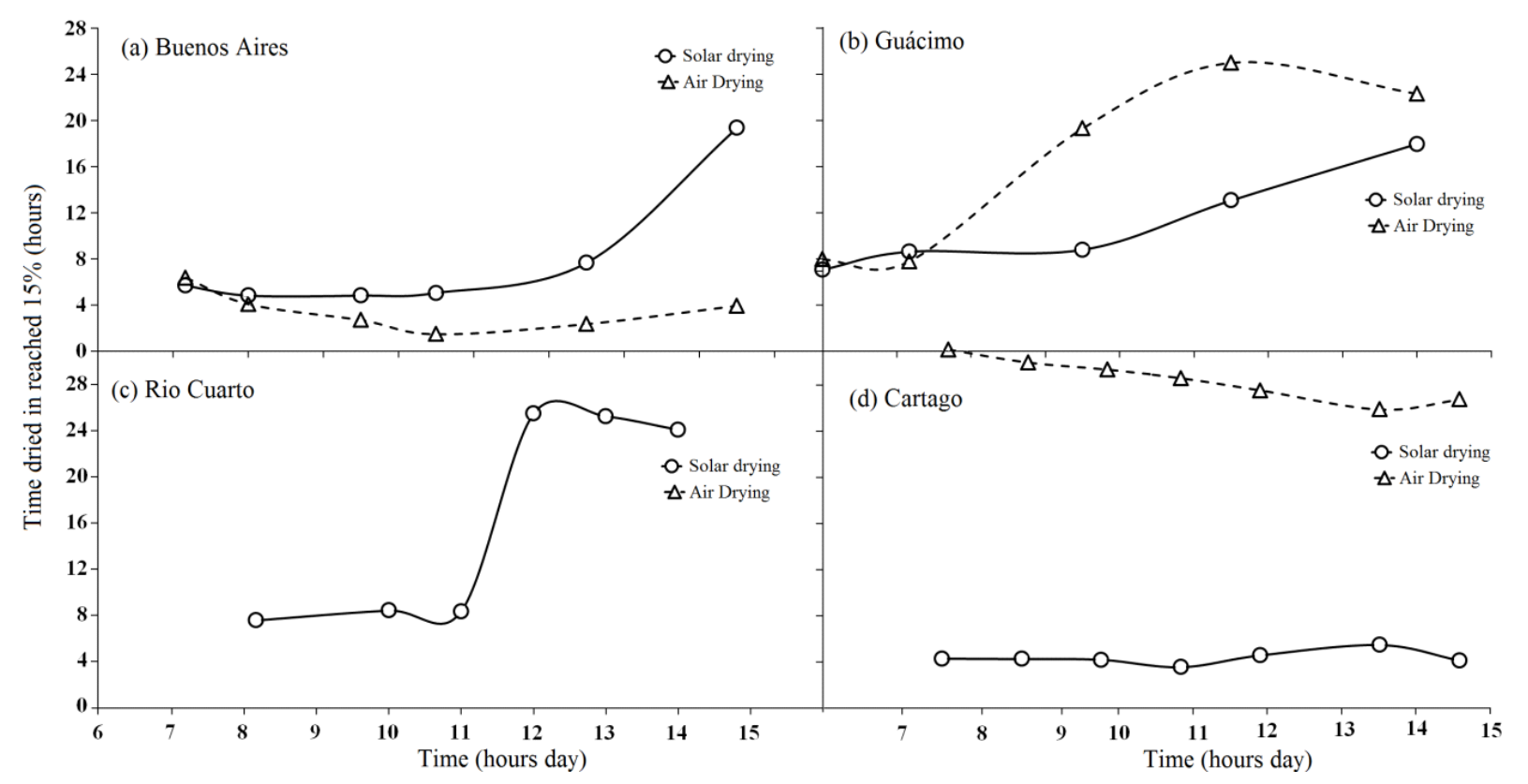

Figure 6 - Drying time at different moisture content in different time across day in four site of Costa Rica. 


\section{CONCLUSIONS}

In Costa Rican locations of low temperature and high environmental RH, such as Río Cuarto, the solar dryer's performance is lacking, because the DT is extended and MC cannot be taken to less than $20 \%$. Another unfavorable condition in Costa Rica is that after 14h00, the dryer's efficiency decreases, as high IRH and low IT are found within the dryer. But, for improving the chamber's conditions, it is possible to use hot air injection to improve temperature in hours where low temperatures and high relative humidity are present, thus, it is possible to dry pineapple fiber to optimal FMC values in DT less than 4 hours, but the time may stretch to 8 hours when conditions are unfavorable.

\section{ACKNOWLEDGEMENTS}

The authors wish to thank The Vicerrectoría de Investigación y Extensión of the Instituto Tecnológico de Costa Rica (ITCR), and Coorporación de Desarrollo Agrícola del Monte S.A. (PINDECO), Ticoverde S.A., Fiffes for their support in supplying material tests.

\section{REFERENCES}

ALVARADO, L. Climatology of the free atmosphere over Costa Rica. Revista Tópicos Meteorológicos y

Oceanográficos, San José, v.8, p.89-115, 2001.

AZHARI, A.; et al. A new approach for predicting solar radiation in tropical environment using satellite images case study of Malaysia. MY. Environment and

Development, Netherlands, v.4, p.373-378, 2008.

COSTALES, R. Application of renewable energy during drying. State of the art and its potential in agricultural production. Instituto Cubano de Investigación de los Derivados de la Caña de Azúcar (ICIDCA), havana, v.44, p.47-53, 2010.

EKECHUKWU, O; NORTON, B. Review of solar energy systems: an overview of solar drying technology. Energy Conversion and Management, oxford, v.40, p.615-655, 1999.
JANJAI, S.; SRISITTIPOKAKUN, N.; BALA, B. Experimental and modeling performances of a roof integrated solar drying system for drying herbs and spices. Energy, Oxford, v.54, p.378-391, 2006.

LOTFALIAN, A.; GHAZAVI, M.; HOSEINZADEH, B. Reviewing drying of drill and spearmint by a solar dryer and comparing with traditional dryers. World Applied Sciences Journal, Dubai, v.8, p.364-368, 2010.

OKALA, N.; et al. Analysis and survey of the application of solar dryers in eastern Nigeria.

International Journal of Agricultural and Biological Engineering, Pequim, v.4, p.79-82, 2011.

PANGAVHANE, D.; SAWHNEY, R.; SARSAVADIA, P. Design, development and performance testing of a new natural convection solar dryer. Energy, Oxford, v.27, p.579-590, 2002.

SALAS, C; MOYA, R; CÓRDOBA, R. Design and construction of a solar drier for lumber. Kurú: Revista Forestal, Cartago, v.13, p.1-13, 2008.

SAMUELSSONA, R.; BURVALLA, J.; RAIDA, J. Comparison of different methods for the determination of moisture content in biomass. Biomass and Bioenergy, Oxford, v.30, p.929-934, 2006.

ULLOA, J.; et al. Tropical agricultural residues and their potential uses in fish feeds: the Costa Rica situation. Waste management, Oxford, v.24, p.87-97, 2004.

WRIGHT, J. 2002. Maps of solar radiation in Costa Rica. Revista Tópicos de Meteorología y Oceanográficos, San José, v.9, p.79-87, 2002.

ZHIMIN, L.; et al. Experimental investigation on solar drying of salted greengages. Renewable Energy, Oxford, v.31, p.837-847, 2006. 